\title{
Redistribution of Syntaxin mRNA in Neuronal Cell Bodies Regulates Protein Expression and Transport during Synapse Formation and Long-Term Synaptic Plasticity
}

\author{
Jiang-Yuan Hu, Xu Meng, and Samuel Schacher \\ Center for Neurobiology and Behavior, Columbia University College of Physicians and Surgeons and New York State Psychiatric Institute, New York, New \\ York 10032
}

Syntaxin has an important role in regulating vesicle docking and fusion essential for neurotransmitter release. Here, we demonstrate that the distribution of syntaxin mRNA in cell bodies of sensory neurons (SNs) of Aplysia maintained in cell culture is affected by synapse formation, synapse stabilization, and long-term facilitation (LTF) produced by 5 -HT. The distribution of the mRNA in turn regulates expression and axonal transport of the protein. Syntaxin mRNA and protein accumulated at the axon hillock of SNs during the initial phase of synapse formation. Significant numbers of granules containing syntaxin were detected in the SN axon. When synaptic strength was stable, both mRNA and protein were targeted away from the axon hillock, and the number of syntaxin granules in the SN axon was reduced. Dramatic increases in mRNA and protein accumulation at the axon hillock and number of syntaxin granules in the SN axon were produced when cultures with stable connections were treated with 5-HT that evoked LTF. Anisomycin (protein synthesis inhibitor) or KT5720 (protein kinase A inhibitor) blocked LTF, accumulation of syntaxin mRNA and protein at the axon hillock, and the increase in syntaxin granules in $\mathrm{SN}$ axons. The results indicate that without significant effects on overall mRNA expression, both target interaction and 5-HT via activation of protein kinase A pathway regulate expression of syntaxin and its packaging for transport into axons by influencing the distribution of its mRNA in the SN cell body.

Key words: syntaxin; mRNA localization; protein expression; axonal transport; sensory neurons; cell culture; Aplysia

\section{Introduction}

The targeting of mRNA to specific locations in polarized cells is one mechanism for regulating the distribution of their translated products critical for development or cell function (Litman et al., 1993; Kislauskis et al., 1994; Bassell et al., 1998; Palacios and St. Johnston, 2001). In neurons, mRNA targeted to the axon hillock (Litman et al., 1993; Hu et al., 2002) or to specific distal locations as a consequence of target interaction (Schacher et al., 1999) or after synaptic activity (Steward and Worley, 2001) can play an important role in site-specific synaptic plasticity. Local translation of targeted mRNA may contribute to synapse formation during development or to synaptic plasticity after stimuli that produce long-term changes in behavior (Casadio et al., 1999; Steward and Schuman, 2001; Schacher and $\mathrm{Wu}, 2002)$. How the changes at distal sites combine with the necessary changes in gene expression and protein synthesis in neuronal cell bodies to produce the long-lasting effects associated with synapse development and activity-dependent plasticity is unknown.

Regulating the expression of molecules critical for transmitter release in the cell bodies for subsequent transport down axons or

Received Nov. 13, 2002; revised Dec. 18, 2002; accepted Dec. 20, 2002.

This research was supported by National Institutes of Health (NIH) Grants MH-60387 and NS-42159, and animals provided by the National Center for Research Resources National Resource for Aplysia at the University of Miami were supported by NIH Grant RR-10294. We thank Rachel Yarmolinsky and Eve Vagg for assistance in preparing the figures, and Drs. Koester and Schwartz for comments on this manuscript.

Correspondence should be addressed to Dr. Samuel Schacher, Center for Neurobiology and Behavior, Columbia University College of Physicians and Surgeons, New York State Psychiatric Institute, 1051 Riverside Drive, New York, NY 10032.E-mail: sms2@columbia.edu.

Copyright $\odot 2003$ Society for Neuroscience $\quad 0270-6474 / 03 / 231804-12 \$ 15.00 / 0$ near the synapses themselves may facilitate synapse formation, specificity, and function during development or after activity that leads to long-term synaptic plasticity. Members of the syntaxin family of proteins are critical elements of the soluble $\mathrm{N}$-ethylmaleimide-sensitive factor attachment protein receptor (SNARE) complex at various sites within neurons, including presynaptic release sites that play a crucial role in vesicle docking and fusion during the release of neurotransmitter (Bennett et al., 1992; Hata et al., 1993; Blasi et al., 1994). Syntaxin expression, at either the mRNA or protein level, may be regulated during the formation of neuromuscular junctions or synapses within the CNS (Igarashi et al., 1996; Sanders et al., 1998; Noakes et al., 1999; Greenlee et al., 2001). Syntaxin expression can be regulated in some areas of the CNS with certain types of electrical stimulation or behavioral training (Davis et al., 1996, 1998, 2000; Hicks et al., 1997). These results suggest that expression of syntaxin, a critical component for synaptic function, may be regulated under conditions leading to long-lasting changes in connectivity between neurons.

The sensory neurons (SNs) of Aplysia can establish specific connections in cell culture that express various forms of shortand long-term synaptic plasticity (Montarolo et al., 1986, 1988; Rayport and Schacher, 1986; Glanzman et al., 1989; Eliot et al., 1994; Sun et al., 1996). Contact with specific targets that initiate synapse formation leads to branch-specific changes in transport and stability of specific mRNAs in the presynaptic neuron (Schacher et al., 1999; Hu et al., 2002). Contact with a specific synaptic target also results in the increased accumulation of some mRNAs that encode for proteins that are shipped to terminals via 
rapid axonal transport (Schacher et al., 1999; Hu et al., 2002). A member of the syntaxin I family was identified in Aplysia neurons and is critical for transmitter release at $\mathrm{SN}$ and cholinergic neuron synapses (Skehel et al., 1995; Smirnova et al., 1995). We therefore examined whether syntaxin mRNA and protein expression and distribution are affected by synapse formation and longterm facilitation (LTF) produced by 5 -HT. We found that distribution of syntaxin mRNA in the cell body of SNs is regulated by target interaction, synapse maturation, and LTF. The differences in mRNA distribution within the SN cell body had a profound effect on expression of syntaxin protein, including its packaging for axonal transport.

\section{Materials and Methods}

Cell culture and electrophysiology. SNs were isolated from pleural ganglia dissected from adult animals ( $80-100 \mathrm{gm})$; motor cells L7 and L11 were isolated from juvenile (1-3 gm) abdominal ganglia and maintained in coculture for 1-5 d as described previously (Rayport and Schacher, 1986; Schacher et al., 1999). Individual SNs were plated in the same culture dish at very low density to prevent cells from contacting each other. Cocultures consisted of one SN with one L7 or one L11 (SN-L7 or SN-L11). In some cases, one coculture of each type was plated in the same dish.

Standard electrophysiological techniques were used to record the amplitude of the EPSP evoked in L7 or L11 with stimulation of each SN (Schacher and Montarolo, 1991; Schacher et al., 1999). Motor cells (L7 and L11) were impaled with a microelectrode (resistance of 15-20 M $\Omega$ ) containing $2.0 \mathrm{M} \mathrm{K}$-acetate, $0.5 \mathrm{~m} \mathrm{KCl}$, and $10 \mathrm{~mm} \mathrm{~K}$-HEPES, pH 7.4, and held at $-85 \mathrm{mV}$. Each SN was stimulated with a brief $(0.3-0.5 \mathrm{msec})$ depolarizing pulse to evoke an action potential using an extracellular electrode placed near the cell body of the SN. The amplitude of the EPSPs evoked in $\mathrm{L} 7$ ranged from $1 \mathrm{mV}$ (day 1) to $55 \mathrm{mV}$ (day 5). Action potentials in SNs never evoked EPSPs in L11 (Glanzman et al., 1989; Schacher and Montarolo, 1991).

LTF of SN-L7 synapses was produced by five bath applications of 5-HT (final concentration of $5 \mu \mathrm{M}$ ) after recording the amplitude of the EPSP (Montarolo et al., 1986) after $4 \mathrm{~d}$ in culture. Each application lasted $5 \mathrm{~min}$ and was separated by $15 \mathrm{~min}$. Cultures were rinsed with a 1:1 mixture of L15 medium and seawater. After the last application, cultures were rinsed with culture medium (1:1 mixture of L15 and hemolymph) and placed back into the incubator, and EPSP amplitudes were reexamined $24 \mathrm{hr}$ later (day 5). Cultures matched for initial EPSP amplitudes received control applications (medium minus 5-HT). Some cultures were incubated for $3 \mathrm{hr}$ in $20 \mu \mathrm{M}$ anisomycin (Montarolo et al., 1986) starting either 30 min before the first application of 5-HT (Aniso + 5-HT) or $6 \mathrm{hr}$ before the first application of $5-\mathrm{HT}$ and washed out $3 \mathrm{hr}$ before first application of 5-HT (Aniso-W + 5-HT). Some cultures were exposed for $2 \mathrm{hr}$ starting $30 \mathrm{~min}$ before the first application of 5-HT to membranepermeable inhibitor of protein kinase A (PKA) (10 $\mu \mathrm{M}$ KT5720; Calbiochem, La Jolla, CA) or of PKC (10 $\mu \mathrm{M}$ chelerythrine; Calbiochem). After final EPSP amplitudes were recorded on day 5 , cultures were rinsed and fixed for in situ hybridization and immunocytochemistry.

In situ hybridization. Antisense oligonucleotide probes were designed to cover specific coding portions of the target sequences used successfully in RT-PCR analyses of the mRNAs, synthesized (Genset, La Jolla, CA), lyophilized, and redissolved in sterile distilled water. The specific antisense oligonucleotide probe sequences were syntaxin, TCTGGCAGGCGTTGTAGTCGTTCATCACCTCCACGAACTTCCGAGACA, which is complementary to nucleotide (nt) 574-527 of its cDNA, and SN-specific protein sensorin, TTAACTCTTCTTGACTCACCAACTGCCTGGATAGCA, which is complementary to nt 304-339 of its cDNA. Their sense probes were also designed for use as nonspecific controls. These probes were labeled at the $3^{\prime}$ end with biotin-ddUTP according to the manufacturer's instructions (Boehringer Mannheim, Indianapolis, IN). All subsequent reagents and solutions used were made with diethyl pyrocarbonate-treated MilliQ water, and care was taken to avoid contamination with RNases.

Cultures were rinsed briefly in artificial seawater and fixed in $0.1 \mathrm{M}$ PBS, pH 7.4, containing 4\% paraformaldehyde and 30\% sucrose for $1 \mathrm{hr}$
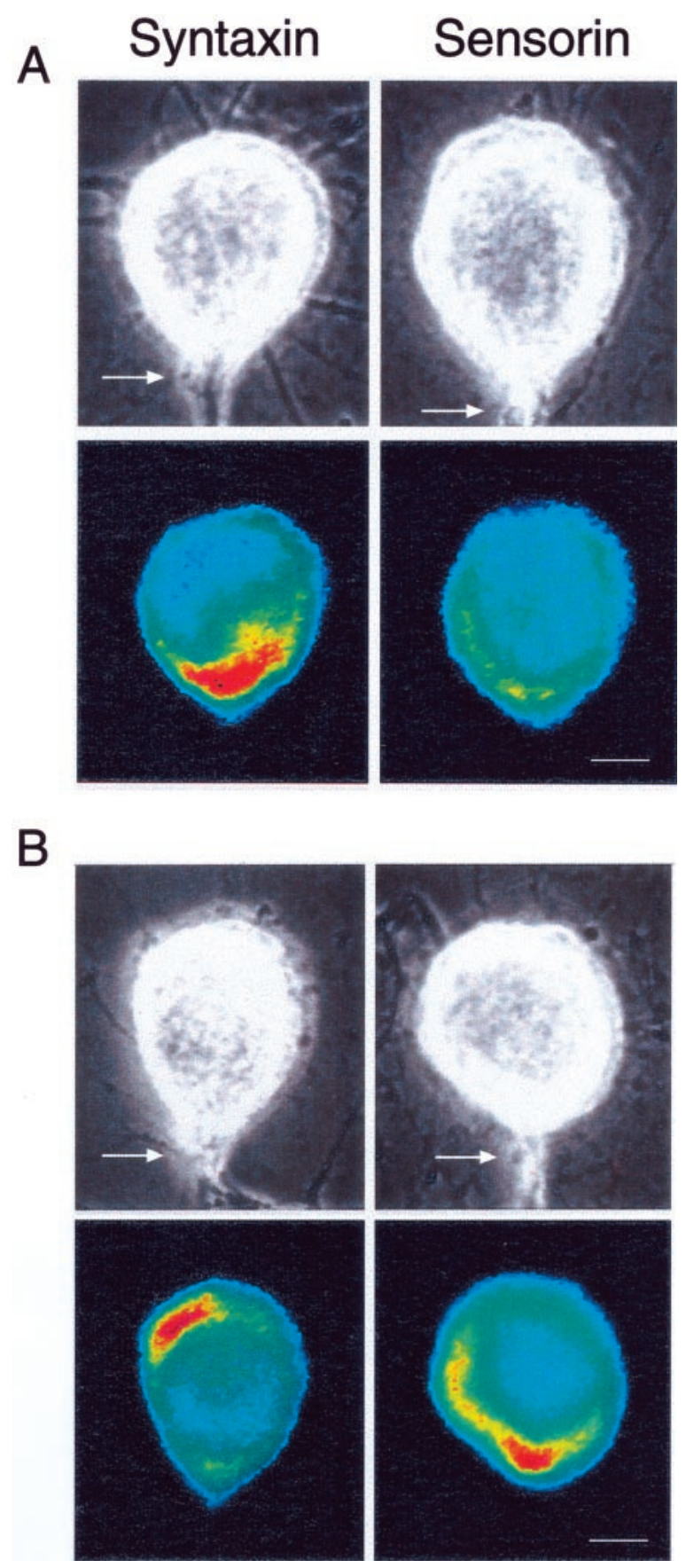

Figure 1. Interaction with L7 leads to opposite changes in the distribution of syntaxin mRNA versus sensorin mRNA. A, Syntaxin mRNA accumulates at the axon hillock on day 1, whereas sensorin mRNA is distributed uniformly. The top micrographs are Nomarski contrast images of each SN cell body with its main axon (arrow) emerging at the $60^{\prime}$ clock position. The bottom micrographs are pseudocolor representation of fluorescent signals (red is high intensity; blue is low intensity) for syntaxin or sensorin mRNA in SNs cultured with L7 for $1 \mathrm{~d}$. Neurites around SN cell bodies belong to both SN and L7. Scale bar, $25 \mu \mathrm{m}$. B, Syntaxin mRNA accumulates away from the axon hillock, but sensorin mRNA accumulates at the axon hillock on day 5 . The top micrographs are Nomarski contrast views of each SN cell body and axon; the bottom micrographs are pseudocolor representations of fluorescent signals for syntaxin and sensorin mRNAs in the SNs cultured with L7 for $5 \mathrm{~d}$. Scale bar, $25 \mu \mathrm{m}$.

at room temperature. The cultures were washed in $0.1 \mathrm{~m}$ PBS three times for $10 \mathrm{~min}$ at room temperature. The cells were digested with $1 \mu \mathrm{g} / \mathrm{ml}$ of proteinase $\mathrm{K}$ in TE buffer $(0.1 \mathrm{M}$ Tris- $\mathrm{HCl}$ with $1 \mathrm{~mm} \mathrm{EDTA,} \mathrm{pH}$ 8.0) for $20 \mathrm{~min}$ at $37^{\circ} \mathrm{C}$, and then washed with $0.1 \mathrm{M}$ PBS three times for $10 \mathrm{~min}$ at room temperature. The cells were postfixed with $4 \%$ paraformaldehyde 
A

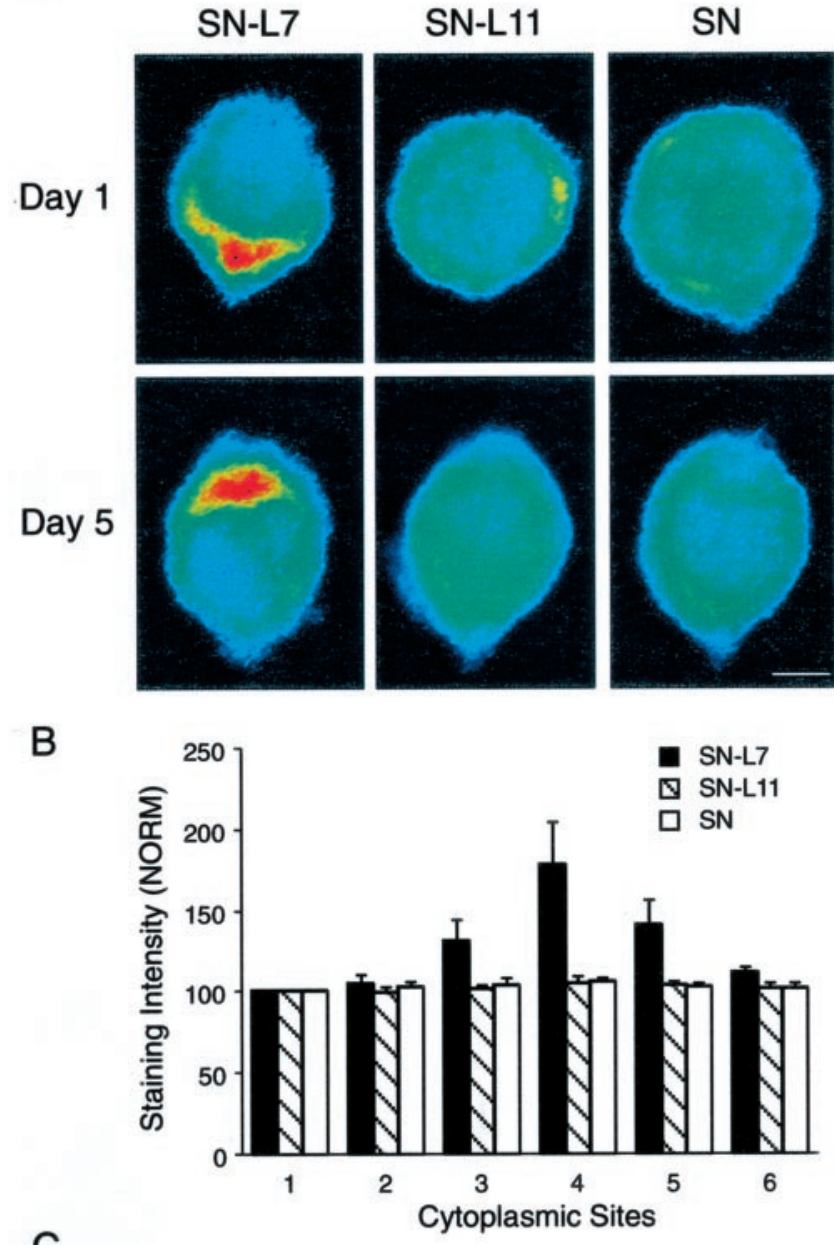

C

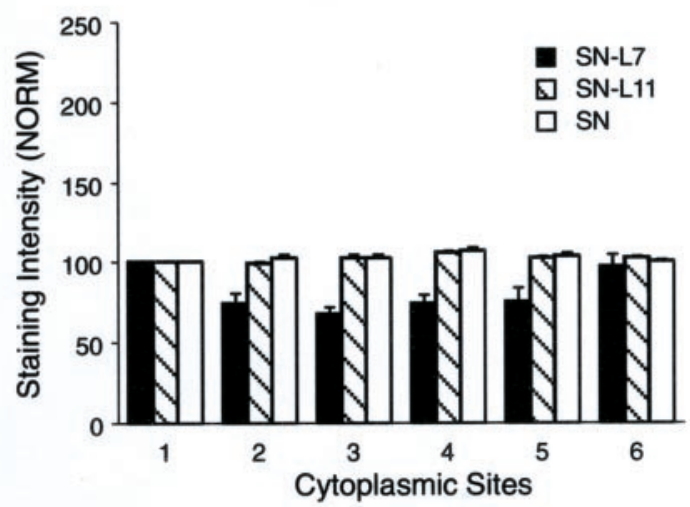

Figure 2. Target interaction regulates the distribution of syntaxin mRNA in SN cell bodies. $A$, Each micrograph is a pseudocolor representation of in situ hybridization signals (red is high intensity; blue is low intensity) for syntaxin mRNA in SNs cultured with L7, L11, or alone for 1 or $5 \mathrm{~d}$. The $\mathrm{SN}$ axons emerge at the $6 \mathrm{o}^{\prime}$ clock position. Syntaxin mRNA accumulates in the region of the axon hillock on day 1 and is excluded from this region on day 5 only when $\mathrm{SN}$ s form synapses with L7. Scale bar, $25 \mu \mathrm{m}$. B, C, Syntaxin mRNA accumulates at the axon hillock of SNs after $1 \mathrm{~d}$ in culture with motor cell $L 7$, whereas it is distributed uniformly when synapses are not formed (B). At $5 \mathrm{~d}$ in culture, however, syntaxin mRNA appears to be excluded from the axon hillock region, whereas it is remains distributed uniformly when $S N$ s are not forming synapses ( $C$ ). The histograms summarize relative intensity at five sites (2-6 corresponding to 2, 4, 6, 8, and 10 $0^{\prime}$ clock positions, respectively) compared with site 1 ( $120^{\prime}$ clock position). The $S \mathrm{~N}$ axon emerges at position 4 ( $60^{\prime}$ clock). The height of each bar is the mean \pm SEM from six cultures for each culture condition at each time point. An ANOVA (two-factor) at each time point indicated a significant difference in the signal intensity for syntaxin mRNA at $1 \mathrm{~d}(\mathrm{df}=10,75 ; F=5.146$; $p<0.001)$ and at $5 \mathrm{~d}(\mathrm{df}=10,75 ; F=7.231 ; p<0.001)$. Interaction with $\mathrm{L} 7$ after $1 \mathrm{~d}$ resulted in significantly greater levels of expression at positions 4 and 5 ( 6 and $80^{\prime}$ clock) compared with in $0.1 \mathrm{M}$ PBS for $10 \mathrm{~min}$ at room temperature and then washed three times for $10 \mathrm{~min}$ at room temperature with $0.1 \mathrm{M}$ PBS. Cells were rinsed in 0.1 $\mathrm{M}$ triethanolamine, $\mathrm{pH} 8.0$, plus $0.25 \%$ acetic anhydride for $10 \mathrm{~min}$ at room temperature, equilibrated in $50 \%$ deionized formamide in $5 \times$ SSC

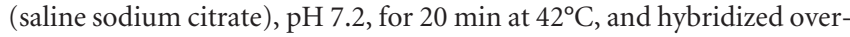
night at $42^{\circ} \mathrm{C}$ in hybridization buffer $(50 \%$ deionized formamide, $5 \times$ SSC, $0.02 \%$ SDS, $2 \%$ blocking reagent) containing $1.5 \mu \mathrm{g} / \mathrm{ml}$ of the biotin-labeled oligonucleotide probes. Unbound probe was washed out with $2 \times$ SSC two times for $15 \mathrm{~min}$ at $42^{\circ} \mathrm{C}$ and with $0.1 \times$ SSC two times for $15 \mathrm{~min}$ at $50^{\circ} \mathrm{C}$. After cultures were equilibrated in buffer I $(0.1 \mathrm{M}$ Tris- $\mathrm{HCl}$ and $0.15 \mathrm{M} \mathrm{NaCl})$ for $2 \mathrm{~min}$ and in buffer II ( $0.1 \mathrm{M}$ Tris- $\mathrm{HCl}$ with $0.15 \mathrm{M} \mathrm{NaCl}, 0.3 \%$ Triton X-100, and 2\% normal goat serum) for $30 \mathrm{~min}$ at room temperature, cells were incubated in streptavidin-FITC (Invitrogen, Gaithersburg, MD; 1:200, diluted in buffer II) for $4 \mathrm{hr}$ at $4^{\circ} \mathrm{C}$. Unbound antibody was washed out with $0.1 \mathrm{M}$ PBS three times for $15 \mathrm{~min}$ at room temperature.

The hybridization signals were visualized directly with fluorescent microscopy and imaged with a Nikon (Tokyo, Japan) Diaphot microscope attached to an SIT (Dage 68; Dage-MTI, Michigan City, IN) video camera, processed by a Dell 310 computer with a personal computer Vision Plus frame grabber, and subsequently stored on compact disks. The specificity of biotin-labeled antisense oligonucleotide probe was examined by hybridizing with labeled sense probe or excess unlabeled probe, or by omitting probe in hybridization solution as well as RNase pretreatment. All controls were negative. Cells were hybridized under the same conditions to reduce variability in different experimental groups.

Immunocytochemistry. Cultures were rinsed briefly in artificial seawater and fixed in $4 \%$ paraformaldehyde dissolved in $0.1 \mathrm{~m}$ PBS with $30 \%$ sucrose, $\mathrm{pH} \mathrm{7.4,} \mathrm{for} 1 \mathrm{hr}$ at room temperature. The cultures were washed in $0.01 \mathrm{M}$ PBS three times for $15 \mathrm{~min}$ at room temperature and were preincubated for $30 \mathrm{~min}$ at room temperature in a blocking solution of $5 \%$ normal goat serum in $0.01 \mathrm{~m}$ PBS with $0.3 \%$ Triton X-100. The cells were then incubated in the mouse monoclonal anti-syntaxin antibody (1:300; Sigma, St. Louis. MO) diluted in $2 \%$ normal goat serum in $0.01 \mathrm{M}$ PBS with $0.3 \%$ Triton $\mathrm{X}-100$ at $4^{\circ} \mathrm{C}$ for $24 \mathrm{hr}$. This antibody recognized a $37 \mathrm{kDa}$ protein (Western blot), the molecular weight of Aplysia syntaxin (Smirnova et al., 1995), derived from pleural ganglia containing the SNs used in the cell cultures (data not shown). The incubated cultures were washed three times in $0.01 \mathrm{M}$ PBS and incubated in FITC-conjugated goat anti-mouse IgG (1:200; Sigma) at $4^{\circ} \mathrm{C}$ for $4 \mathrm{hr}$. For double label of syntaxin mRNA and protein in the same preparation, cultures were first processed for in situ hybridization using the methods described in the section above. After the SNs were photographed, the cultures were then processed for immunocytochemistry as above, but cultures were incubated with Texas Red-conjugated goat anti-mouse IgG (1:200; Sigma). After washing three times in $0.01 \mathrm{~m}$ PBS, cultures were imaged directly with fluorescent microscopy. To test the specificity of the primary antibody, controls were performed, including the substitution of normal rabbit sera for the primary antibody and omission of the primary antibody, all of which did not show any sign of immunocytochemical reaction. In addition, the $37 \mathrm{kDa}$ band on Western blots was not detected when the antibody was preincubated with its cognate peptide. To reduce variability in staining, the cultures from the different experimental and control groups were immunostained at the same time and under the same conditions.

Quantification and data analysis. The NIH Scion software package was used to quantify average pixel intensities for hybridized and immunostained signal of syntaxin in SN cell bodies. For examining distribution within the SN cell body, pixel intensity was averaged for six separate $5 \times$ $5 \mu \mathrm{m}$ squares within the peripheral cytoplasm of each $\mathrm{SN}$ cell body. The squares were positioned at the following equivalent clock locations: 12, 2,

interaction with $\mathrm{L} 11(F=5.554, p<0.02 ; F=4.358, p<0.04)$ or SNs in culture alone $(F=$ $5.402, p<0.02 ; F=4.598, p<0.03)$. By day 5 , interaction with $\mathrm{L} 7$ resulted in significantly lower levels of syntaxin mRNA expression at positions 3,4 , and 5 (4-8 $0^{\prime}$ clock) compared with interaction with L11 ( $F$ values from 6.604 to $9.988 ; p<0.01$ ) or in SNs cultured alone ( $F$ values from 6.678 to $10.018 ; p<0.01)$. 
A

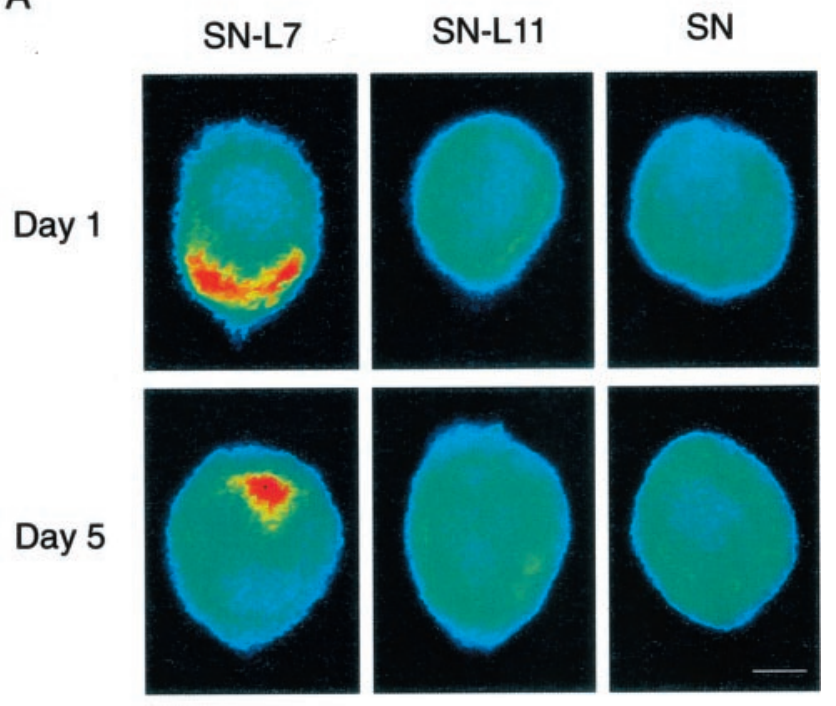

B

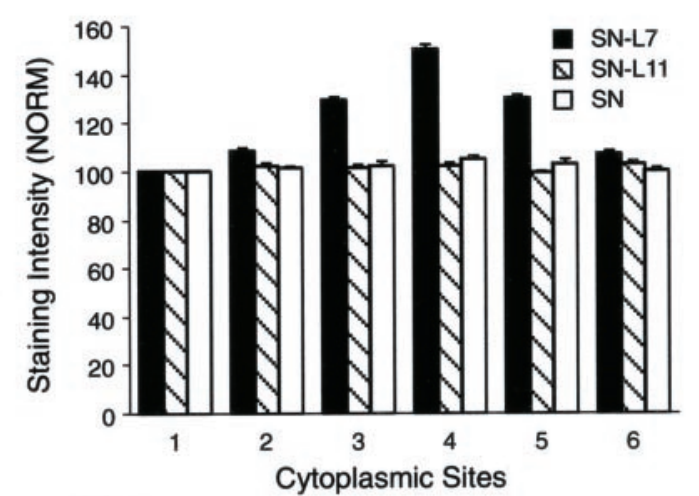

C

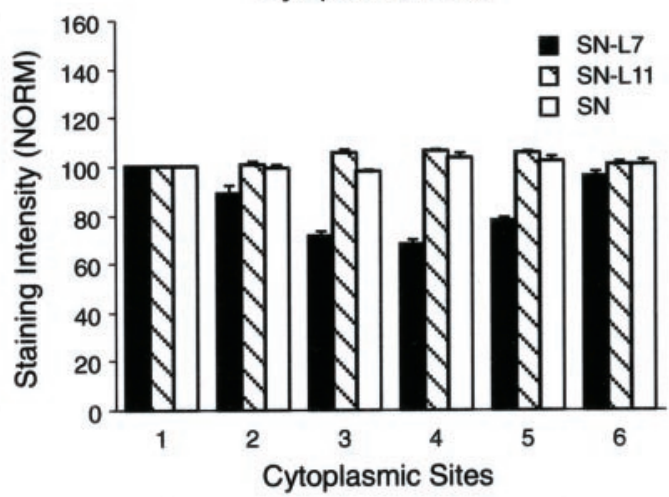

Figure 3. Target interaction regulates the distribution of syntaxin protein in SN cell bodies. A, Each micrograph is a pseudocolor representation of immunocytochemical signals (red is high intensity; blue is low intensity) for syntaxin in SN cultured with L7, L11, or alone for 1 or $5 \mathrm{~d}$. The SN axons emerge at the $60^{\prime}$ clock position. Syntaxin accumulates in the region of the axon hillock on day 1 but is excluded from this region on day 5 . Scale bar, $25 \mu \mathrm{m} . B, C$, Syntaxin accumulates at the axon hillock region of SNs only after $1 \mathrm{~d}$ in culture with motor cell L7 (B). At $5 \mathrm{~d}$ in culture, syntaxin appears to be excluded from the axon hillock region but is distributed uniformly when $\mathrm{SN}$ is not forming synapses ( $O$. The histograms summarize relative intensity at five sites (2-6 corresponding to 2, 4, 6, 8, and $10 o^{\prime}$ 'lock positions, respectively) compared with site 1 (12 o'clock position). The height of each bar is the mean \pm SEM from 6-10 cultures for each condition at each time point. An ANOVA (two-factor) at each time point indicated a significant difference in the signal intensity for syntaxin at day 1 ( $\mathrm{df}=10$, $95 ; F=8.514 ; p<0.001$ ) and at day $5(\mathrm{df}=10,90 ; F=8.168 ; p<0.001)$. Interaction with $\mathrm{L} 7$ after $1 \mathrm{~d}$ resulted in significantly greater levels of expression at positions 3,4 , and 5 (4-80'clock) compared with interaction with L11 ( $F$ values from 11.826 to $17.444 ; p<0.01$ ) or SNs in culture alone ( $F$ values from 11.840 to $16.464 ; p<0.01)$. By day 5 , interaction with $L 7$ resulted in significantly lower levels of syntaxin expression at positions 3,4, and 5 (4,6, and $80^{\prime}$ clock) compared with interaction with $\mathrm{L} 11$ ( $F$ values from 10.999 to $15.993 ; p<0.01$ ) or in SNs cultured alone (Fvalues from 9.210 to 14.878; $p<$ $0.01)$.
$4,6,8$, and 10 (sites 1 through 6 , respectively). The cytoplasm of the cell body adjacent to the $\mathrm{SN}$ axon was positioned at 6 o'clock (position 4), and the signal intensity at the opposite side away from the axon (12 o'clock or position 1) was normalized as $100 \%$. For each cell, the intensities at the other five locations were normalized to that measured at the 12 o'clock location. Values for overall expression of syntaxin mRNA or protein in each SN cell body were determined by averaging the pixel intensities for the six locations used to monitor distribution. In addition, the immunostained syntaxin granules in the SN axon (initial $100 \mu \mathrm{m}$ ) were counted for each experimental condition. Data were expressed as means \pm SEM. The overall effects of target interaction, 5-HT application in the presence or absence of anisomycin, were determined by ANOVA, and specific differences for the different treatments were determined by the Scheffe multiple-comparison tests.

\section{Results}

The SNs of Aplysia rapidly form synaptic connections with motor cell L7 but fail to establish connections with L11 (Glanzman et al., 1989; Schacher and Montarolo, 1991). Target interaction with L7 leads to a number of changes in SNs (Glanzman et al., 1989; Sun and Schacher, 1996), including an increase in accumulation in the axon hillock of mRNA encoding the neuropeptide sensorin after $3 \mathrm{~d}$ in culture (Hu et al., 2002), and high levels of peptide expression at SN varicosities contacting motor cell L7 (Santarelli et al., 1996). SNs interacting with L11 or SNs cultured alone fail to accumulate sensorin mRNA in the axon hillock after $3 \mathrm{~d}$ in culture (Hu et al., 2002). An mRNA encoding an integral membrane protein, Aplysia cell adhesion molecule (apCAM), accumulated at the axon hillock but failed to show differences in accumulation with target interaction or synapse formation (Hu et al., 2002). These results suggest that mRNAs accumulate at the axon hillock if they encode proteins that are transported via membranous organelles to distal sites, and the targeting of some of them is regulated with synapse formation. Because sensorin protein and mRNA also accumulate in SN varicosities (Santarelli et al., 1996; Schacher et al., 1999; Hu et al., 2002), changes in accumulation at the axon hillock may reflect a target- and synapse-dependent effect on mRNA encoding for molecules that play an important and direct role in synapse function. To test this idea we used in situ hybridization to examine whether synapse formation and target interaction affect the distribution of mRNA encoding the Aplysia homolog of syntaxin, which has been shown to play an important role in transmitter release in Aplysia (Skehel et al., 1995; Smirnova et al., 1995). We measured the staining intensity of the labeled probe that recognizes syntaxin in six areas of cytoplasm of SN cell bodies corresponding to the following clock positions: 12 (position 1 and opposite the axon hillock of the $\mathrm{SN}$ ), $2,4,6$ (where axon emerges), 8 , and 10 . We then used immunocytochemical methods to determine the effects of target interaction on the distribution of syntaxin protein within the cytoplasm of SN cell bodies and axons.

Synapse formation and maturation lead to changes in distribution of syntaxin mRNA and protein in $\mathrm{SN}$ cell bodies Aplysia SNs form synaptic connections with L7 within $20 \mathrm{hr}$ of coculture (Sun and Schacher, 1996). The strength of the connections increases over the next $48-72 \mathrm{hr}$, reaching a stable state by 4 d in culture (Montarolo et al., 1986; Glanzman et al., 1989; Bank and Schacher, 1992). Using in situ hybridization, we examined at different time points the distribution of syntaxin mRNA in the cell body of SNs cultured with L7, with L11, or alone.

Syntaxin mRNA was distributed asymmetrically in the cell bodies of SNs that form synaptic connections with L7 on both day 1 and day 5 (Fig. $1 A, B$ ). During the initial phase of synapse for- 


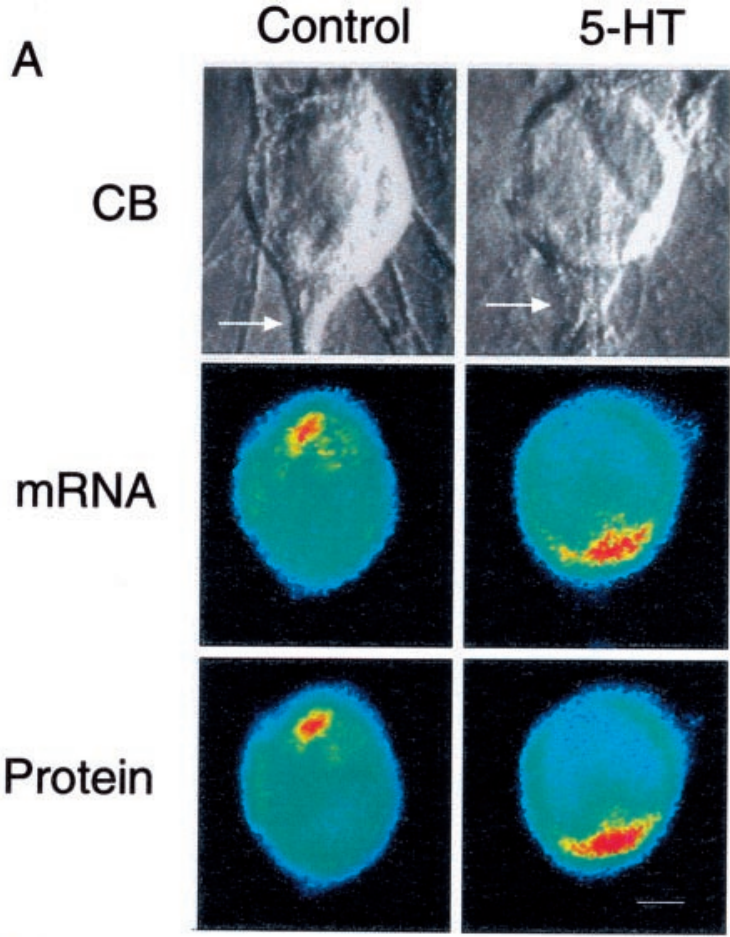

B
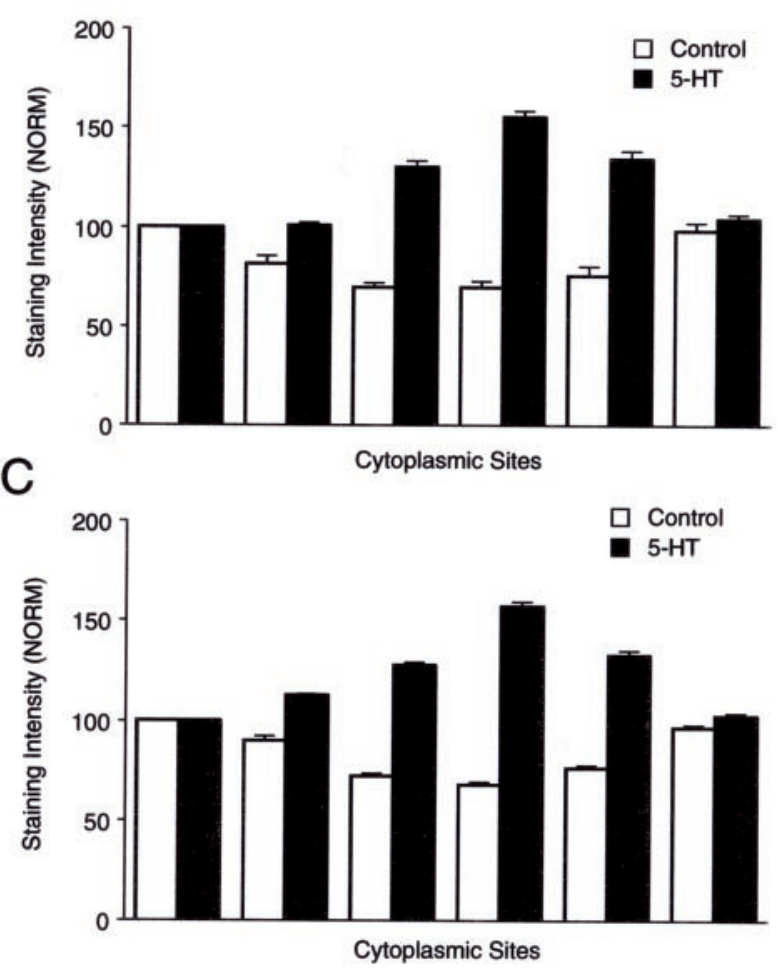

Figure 4. Distribution of syntaxin mRNA and protein is altered on day 5 by 5 -HT that produces LTF. A, Double-label images reveal parallel distributions for syntaxin mRNA (in situ hybridization) and protein (immunocytochemistry) in SN cell bodies. The top micrographs are Nomarski contrast images of each SN cell body and initial axon segment. The middle micrographs are pseudocolor representations of in situ hybridization signals for syntaxin mRNA in these SNs fixed $24 \mathrm{hr}$ after control or 5-HT treatments. The bottom micrographs are pseudocolor representations of immunocytochemical signals for syntaxin in the same SNs. Syntaxin mRNA and protein accumulate in the region of the axon hillock after 5-HT is applied to cultures with stable connections but remain excluded from this area with control treatment. Scale bar, 20 $\mu \mathrm{m} . B, C$, The histograms summarize the effects of $5-\mathrm{HT}$ on the distribution of syntaxin mRNA $(B)$ and protein $(C)$. The height of each bar is the mean \pm SEM from 10-18 cultures for each mation after $1 \mathrm{~d}$ in culture, syntaxin mRNA accumulated in the region of the axon hillock compared with other areas of the cytoplasm (Fig. 1A). With maturation and stabilization of the synaptic connections at $5 \mathrm{~d}$ in culture, syntaxin mRNA was still distributed asymmetrically in SNs that contact L7, but now the mRNA levels at the axon hillock were generally lower than other areas of the SN cytoplasm (Fig. $1 B$ ). Overall levels of expression on day 5 were not significantly different $(p>0.7)$ from that observed on day 1: average intensity on day 1 was $22.8 \pm 1.6$ (arbitrary units) versus $21.2 \pm 1.7$ on day 5 .

Although targeting of syntaxin mRNA to the axon hillock of SNs decreased with synapse maturation, the targeting of sensorin mRNA to the axon hillock of SNs forming synaptic connections with L7 increased during the same period (Fig. $1 A, B$ ). This supports the idea that different classes of mRNAs may be targeted to the axon hillock by different sets of mechanisms and binding proteins or chaperones.

Syntaxin mRNA was distributed uniformly in SNs contacting L11 or cultured alone after 1 or $5 \mathrm{~d}$ in culture (Fig. 2). Overall expression of syntaxin mRNA was slightly higher (but not significant; $p>0.05$ ) in SNs contacting L7 on both day 1 and day 5 compared with levels of expression in SNs contacting L11 or cultured alone. The targeting of syntaxin mRNA to the axon hillock of SNs is regulated by interaction with specific postsynaptic neurons and synapse formation in both a positive and negative direction.

Does the distribution of syntaxin mRNA in SN cell bodies affect the expression and distribution of the translated product? The expression and distribution of syntaxin paralleled the distribution of its mRNA (Fig. 3). After $1 \mathrm{~d}$ in culture, syntaxin was enriched at the axon hillock when contacting L7, whereas it was distributed at a uniform low level in cell bodies of SNs cultured alone or with L11 (Fig. 3A,B). The same distribution was observed after $5 \mathrm{~d}$ in SNs cultured alone or with L11 (Fig. 3A,C). However, syntaxin expression was at the lowest level at the axon hillock compared with other areas of cytoplasm for SNs cultured with L7 after $5 \mathrm{~d}$ in culture. Overall levels of protein expression were higher in SN-L7 cultures compared with SN-L11 $(p<0.05)$ or SN-alone cultures $(p<0.05)$. Overall levels of syntaxin expression in SN-L7 cultures on day 1 were not significantly different from syntaxin expression in SN-L7 cultures on day 5 (intensity of $27.0 \pm 1.1$ units on day 1 vs $27.4 \pm 0.8$ units on day $5 ; p>$ $0.7)$. Both expression and targeting of some proteins in the cytoplasm of the cell body of neurons may be a consequence of the targeting of its mRNA within the cell body.

\section{Distribution of syntaxin mRNA and protein is regulated during LTF}

Repeated applications of 5-HT produce long-term increases in the efficacy of stable SN-L7 synapses formed in culture that are accompanied by the formation of new $\mathrm{SN}$ varicosities and transmitter release sites (Montarolo et al., 1986; Glanzman et al., 1989; Bailey et al., 1992). In our experiments, 5-HT produced a signif-

treatment in each assay. They include cultures analyzed with the double-label procedure (4 cultures for each treatment). An ANOVA (two-factor) indicated a significant difference in the signal intensity for syntaxin mRNA ( $d f=5,130 ; F=56.088 ; p<0.001)$ and protein ( $d f=$ $5,120 ; F=114.046 ; p<0.001)$. Treatment with $5-\mathrm{HT}$ resulted in significantly higher levels of expression of syntaxin mRNA $(B)$ at positions 3, 4, and 5 (4-8 $0^{\prime}$ clock) compared with controls ( $F$ values from 8.294 to $16.315 ; p<0.01$ ). Treatment with 5 -HT also resulted in significantly higher levels of syntaxin protein expression ( $C$ at positions 3, 4, and 5 (4-8 $0^{\prime}$ clock) compared with controls (Fvalues from 23.612 to $28.509 ; p<0.01$ ). 
A

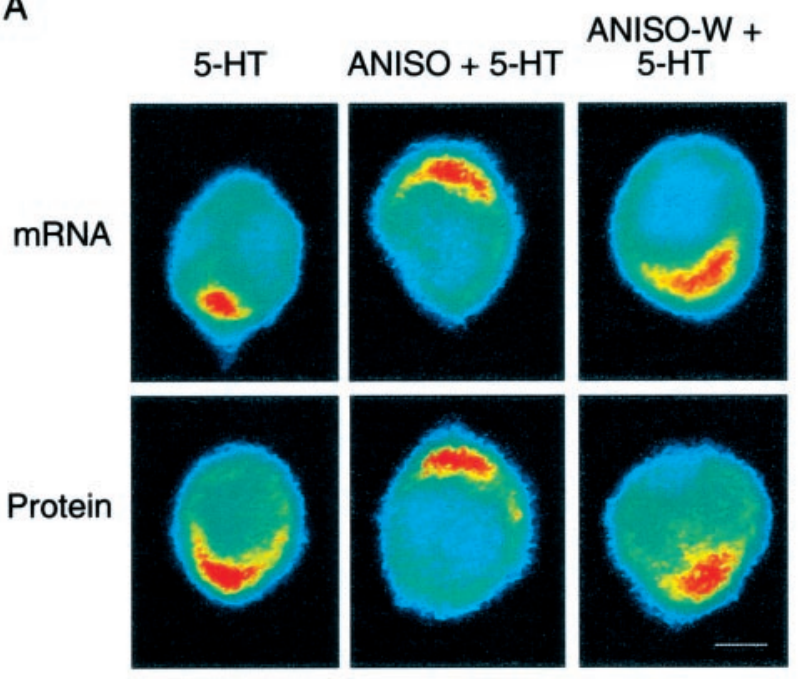

B

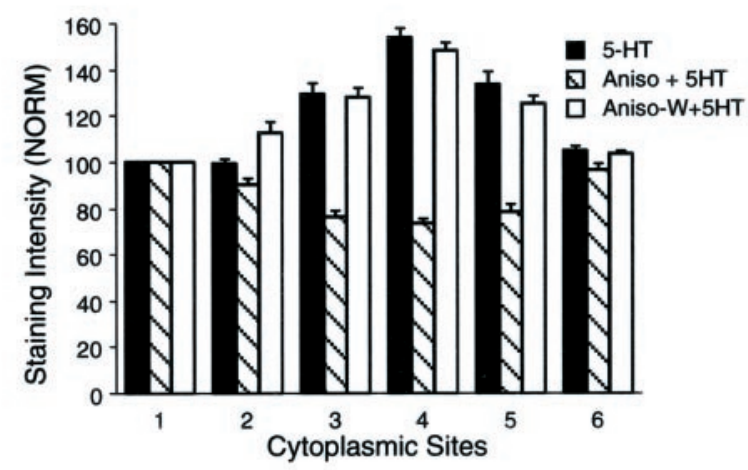

C

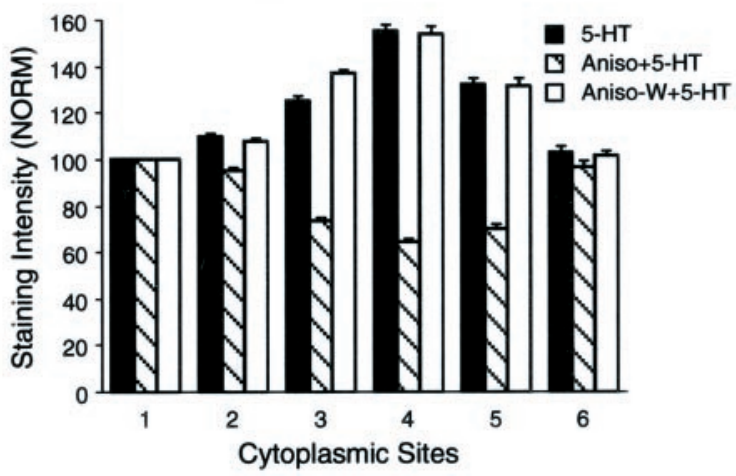

Figure 5. The effects of 5-HT on the distribution of syntaxin mRNA and protein require new protein synthesis. $A$, The top micrographs are pseudocolor representations of in situ hybridization signals for syntaxin mRNA in SNs cultured with L7 for $5 \mathrm{~d}$ and fixed $24 \mathrm{hr}$ after $5-\mathrm{HT}$ (5-HT), $5-\mathrm{HT}$ in the presence of anisomycin (ANISO $+5-\mathrm{HT})$, or $5-\mathrm{HT} 3 \mathrm{hr}$ after washout of anisomycin (ANISO-W + 5-HT). The bottom micrographs are pseudocolor representations of immunocytochemical signals for syntaxin in SNs $24 \mathrm{hr}$ after the same treatments. The accumulation of syntaxin $\mathrm{mRNA}$ and protein in the region of the axon hillock is blocked when 5-HT is applied in the presence of anisomycin. After washout of anisomycin, 5 -HT treatment results in mRNA and protein accumulation in the region of the axon hillock. Scale bar, $25 \mu \mathrm{m} . B, C$, The histograms summarize the effects of anisomycin on 5 -HT producing changes in the distribution of syntaxin mRNA $(B)$ and protein $(C)$. The height of each bar is the mean \pm SEM from 7-10 cultures for each treatment in each assay. An ANOVA (two-factor) indicated a significant difference in the signal intensity for syntaxin $\mathrm{mRNA}(\mathrm{df}=10,120 ; F=30.258 ; p<0.001)$ and protein ( $\mathrm{df}=$ $10,90 ; F=54.955 ; p<0.001)$. Treatment with $5-\mathrm{HT}$ in the presence of anisomycin resulted in significantly lower expression $24 \mathrm{hr}$ later at positions 3,4 , and 5 (4-80' 1 lock) of syntaxin mRNA ( $B$ ) compared with 5 -HT alone ( $F$ values from 13.303 to $16.074 ; p<0.01$ ) or 5 -HT applied after anisomycin washout ( $F$ values from 14.139 to $14.689 ; p<0.01$ ). Treatment with 5 -HT in the presence of anisomycin also resulted in significantly lower expression of syntaxin $(C)$ at positions 3, 4, and 5 (4-8 $0^{\prime}$ clock) compared with 5-HT alone ( $F$ values from 17.174 to 21.943; $p<$ 0.01 ) or 5-HT applied after anisomycin washout ( $F$ values from 16.748 to 21.908). icant increase in EPSP amplitude $(11.3 \pm 0.4 \mathrm{mV} ; n=26$ cultures), whereas control treatment had little effect on EPSP amplitude $(0.5 \pm 0.4 \mathrm{mV} ; n=20$ cultures). We therefore examined whether 5-HT affects the expression and distribution of syntaxin mRNA and protein after synapses have stabilized.

Repeated applications of 5-HT resulted in a significant accumulation of syntaxin mRNA at the axon hillock of the SN cell body (Fig. $4 A, B$ ). The relative level of syntaxin mRNA in the axon hillock was now comparable with that observed after $1 \mathrm{~d}$ of coculture with L7. Overall expression of syntaxin mRNA was not significantly affected by 5-HT (Fig. 5A). The average intensity for control cultures was $22.9 \pm 1.1$ units versus $23.2 \pm 1.4$ units for cultures treated with 5-HT $(p>0.8)$. Thus stable connections were affected by 5-HT; syntaxin mRNA was retargeted to the axon hillock of the SN.

The distribution of syntaxin protein paralleled the distribution of its mRNA (Fig. $4 A, C$ ). Using a double-label procedure, we examined the same cultures as in Figure $4 A$ with immunocytochemical methods. Syntaxin levels in the SNs were enriched at the axon hillock after 5-HT applications. As in previous control preparations, protein levels were lowest at the axon hillock compared with other areas of the SN cytoplasm when cultures were treated with control solutions. Overall expression of syntaxin was not affected by 5 -HT; average intensity for controls was $27.2 \pm$ 0.5 units versus $27.4 \pm 0.6$ units for cultures treated with 5 - HT $(p>0.8)$. The effect of 5-HT on mRNA distribution has downstream consequences on protein distribution.

Redistribution of syntaxin mRNA and protein produced by 5-HT are dependent on protein synthesis and activation of the PKA pathway

The expression of LTF by SN-L7 synapses is dependent on protein synthesis (Montarolo et al., 1986). Treatment with 5-HT in the presence of anisomycin failed to produce a significant change in EPSP amplitude measured $24 \mathrm{hr}$ later $(-0.4 \pm 0.3 \mathrm{mV} ; n=17$ cultures). Treatment with 5 -HT beginning $3 \mathrm{hr}$ after washout of a pretreatment with anisomycin, when protein synthesis resumes at or near normal levels, resulted in a significant increase in EPSP amplitude (9.5 $\pm 0.6 \mathrm{mV} ; n=14$ cultures). We therefore examined whether protein synthesis is required for the changes produced by $5-\mathrm{HT}$ in the distribution of syntaxin mRNA and protein.

Anisomycin applied during the application of 5-HT had a significant effect on mRNA and protein distributions in the cell bodies of SNs (Fig. 5). The highest levels of mRNA expression remained outside the axon hillock (Fig. 5A,B). Cultures treated with 5-HT after washout of the anisomycin (Aniso-W + 5-HT) showed the same effect as cultures treated with 5-HT alone; syntaxin mRNA accumulated at the axon hillock (Figs. $5 A, B$ ). The expression of syntaxin paralleled the expression of its mRNA (Fig. 5A,C). Anisomycin blocked enrichment at the axon hillock when present during the 5-HT applications but failed to have an effect when applied before 5-HT applications. The changes in mRNA distribution and subsequent protein distribution produced by $5-\mathrm{HT}$ requires the synthesis of a protein(s) that targets syntaxin mRNA to the axon hillock.

LTF of SN synapses produced by 5-HT is mediated primarily by its actions on the PKA pathway that regulates phosphorylation of substrate proteins and expression of specific transcription factors and other genes (Greenberg et al., 1987; Schacher et al., 1988; Dash et al., 1990, 1993; Bacskai et al., 1993; Byrne et al., 1993; Alberini et al., 1994; Hegde et al., 1997; Muller and Carew, 1998; 


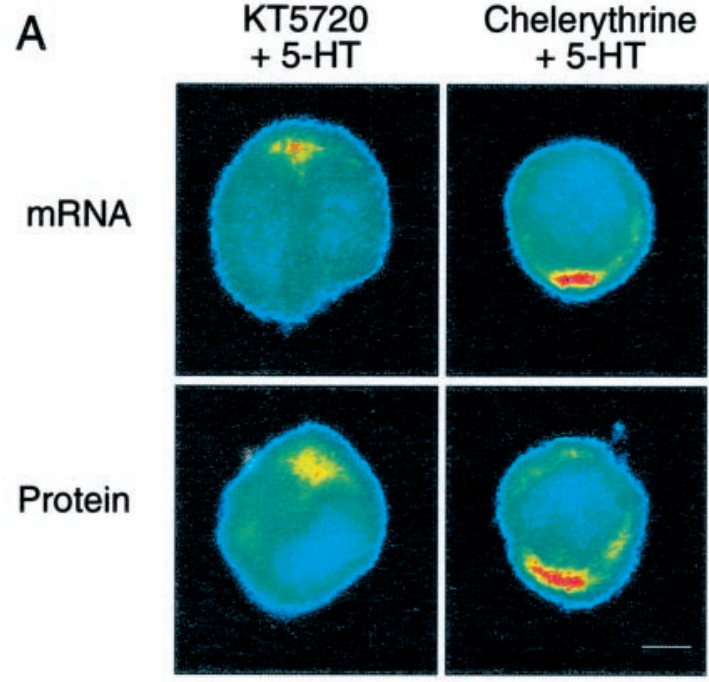

B
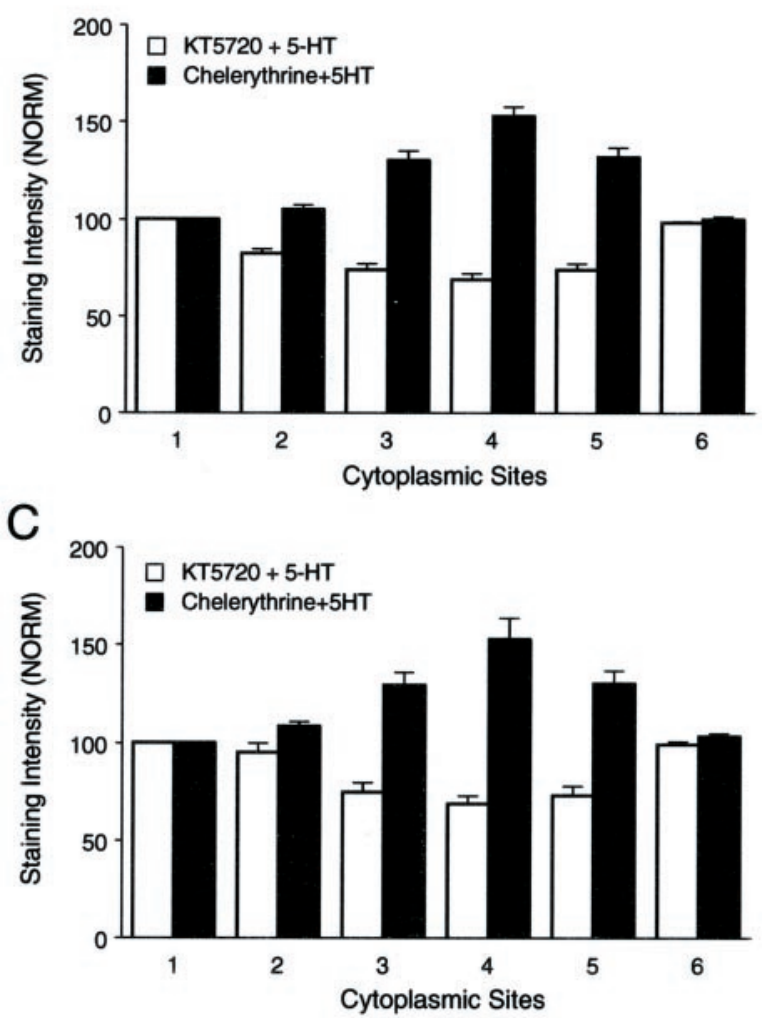

Figure 6. The effects of 5-HT on the distribution of syntaxin mRNA and protein require activation of the PKA pathway. A, The top micrographs are pseudocolor representations of in situ hybridization signals for syntaxin mRNA in SNs cultured with L7 and fixed $24 \mathrm{hr}$ after 5 - $\mathrm{HT}$ applied in the presence of KT5720 or chelerythrine. The bottom micrographs are pseudocolor representations of immunocytochemical signals for syntaxin in SNs $24 \mathrm{hr}$ after the same treatments. The accumulation of syntaxin mRNA and protein in the region of the axon hillock is blocked when 5 - $\mathrm{HT}$ is applied in the presence of KT5720 but not chelerythrine. Scale bar, $25 \mu \mathrm{m}$. B, C, The histograms summarize the effects of the two kinase inhibitors on 5-HT producing changes in the distribution of syntaxin mRNA ( $B$ ) and protein ( $C$. The height of each bar is the mean \pm SEM from seven cultures for each treatment in each assay. An ANOVA (two-factor) indicated a significant difference in the signal intensity for syntaxin mRNA ( $d f=$ $5,60 ; F=81.856 ; p<0.001)$ and protein $(\mathrm{df}=5,60 ; F=30.992 ; p<0.001)$. Treatment with 5-HT in the presence of KT5720 resulted in significantly lower expression $24 \mathrm{hr}$ later at positions 3, 4, and 5 (4-8 $\mathrm{o}^{\prime}$ clock) of syntaxin mRNA $(B)$ compared with 5 -HT in the presence of chelerythrine ( $F$ values from 9.484 to $16.333 ; p<0.01)$. Treatment with 5 -HT in the presence of KT5720 also resulted in significantly lower expression of syntaxin protein ( $C$ at positions 3, 4, and 5 (4-80'clock) compared with 5-HT in the presence of chelerythrine ( $F$ values from 6.431 to $7.184 ; p<0.01$ ).
Chain et al., 1999). Treatment with 5-HT also activates PKC activity (Sossin et al., 1994), which appears to contribute little to expression of LTF measured at $24 \mathrm{hr}$ or later (Wu et al., 1995). We tested whether the actions of 5-HT on the distribution of syntaxin mRNA and protein were influenced by kinase activation by incubating cultures with inhibitors of different kinases during 5-HT treatment. Incubation with the PKA inhibitor KT5720 (Angers et al., 2002) but not a PKC inhibitor, chelerythrine (Sutton and Carew, 2000), blocked LTF. EPSP amplitudes failed to increase significantly $(1.1 \pm 0.6 \mathrm{mV} ; n=14$ cultures $)$ when 5 -HT was applied in the presence of KT5720 but increased significantly (9.2 $\pm 0.5 \mathrm{mV} ; n=14$ cultures) when 5 -HT was applied in the presence of chelerythrine. The PKA inhibitor KT5720 also blocked the effects of 5-HT on the redistribution of syntaxin mRNA and protein (Fig. 6). In the presence of chelerythrine, 5 -HT produced a redistribution of both $\mathrm{mRNA}$ and protein, resulting in the accumulation of syntaxin mRNA and protein at the axon hillock. The actions of 5-HT appear to require PKAdependent changes in expression or phosphorylation of gene product or products that target syntaxin mRNA to the axon hillock.

Target interaction, synapse formation, and LTF regulate packaging of syntaxin for axonal transport

Although syntaxin proteins are synthesized in the cell body of SNs, one of its important functions is in its interaction with other members of the SNARE complex, in which it contributes to vesicle docking and fusion at transmitter release sites. Syntaxin protein synthesized in the cell body must be transported to terminals via axonal transport within membranous organelles. We therefore examined whether the number of granules staining with anti-syntaxin antibodies is influenced by target interaction, synapse formation, and LTF. There was a correlation between a high accumulation of syntaxin mRNA at the axon hillock of the SN with a high number of syntaxin antibody-labeled granules in SN axons (Figs. 7, 8)

A significant number of labeled granules were detected in SN axons after $1 \mathrm{~d}$ of contact with L7 compared with the number of labeled granules detected in SN axons after $5 \mathrm{~d}$ of contact with L7 (Fig. $7 A, B$ ). On average, $3.7 \pm 0.4$ granules were observed in the initial axon segment of SNs contacting L7 after $1 \mathrm{~d}$ in culture $(n=$ 9). After $5 \mathrm{~d}$ in culture only $0.6 \pm 0.1$ granules $(n=14)$ were detected in the axons of SNs contacting L7. Few granules $(0.3 \pm$ 0.2 and $0.5 \pm 0.2$ ) were detected in axons of SNs contacting L11 or in SNs cultured alone $(0.4 \pm 0.2$ and $0.3 \pm 0.2)$ after 1 and $5 \mathrm{~d}$, respectively (data not shown). The number of granules in $\mathrm{SN}$ axons that may be destined for transport to distal synaptic sites parallels the accumulation of mRNA and protein in the axon hillock of the SN and requires interaction with the appropriate target.

Differences in the number of labeled granules in SN axons were also detected after treatment with 5-HT (Fig. 7C,D). SNs expressing LTF contained $4.3 \pm 0.4$ granules in the initial segment of SN axons ( $n=12$ cultures) compared with $0.6 \pm 0.2$ granules detected in stable control cultures ( $n=10$ cultures).

Blocking LTF with anisomycin or the PKA inhibitor during 5-HT application also affected the number of labeled granules detected in SN axons (Fig. 8). After applications of 5-HT in the presence of anisomycin, we detected $0.7 \pm 0.3$ granules in SN axons ( $n=7$ cultures). In contrast, we detected $3.7 \pm 0.3$ granules in SN axons ( $n=7$ cultures) when 5 -HT was applied after 
A

Day 1
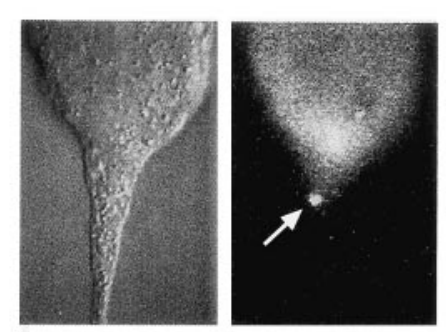

Day 5
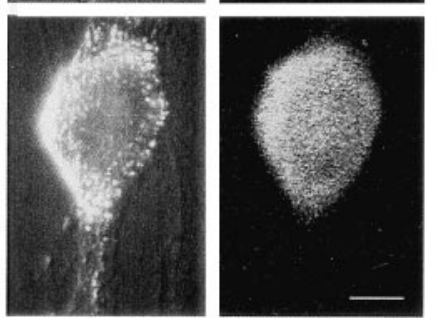

C
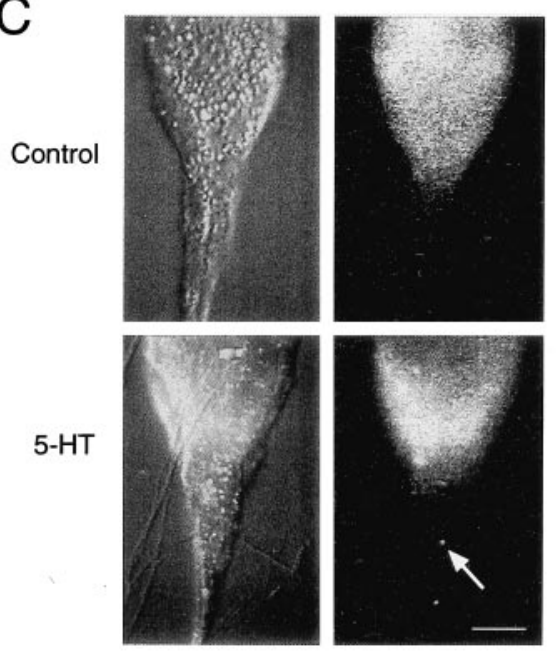

B

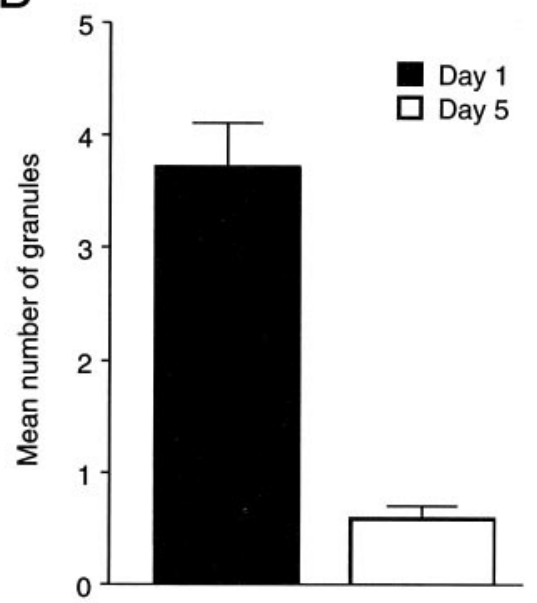

$\mathrm{D}$

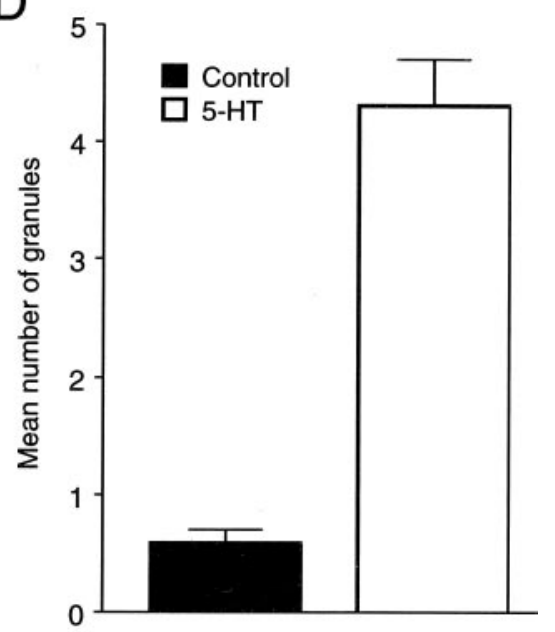

Figure 7. The number of granules in $\mathrm{SN}$ axons staining positively for syntaxin is high when syntaxin mRNA accumulates in the axon hillock region of the $\mathrm{SN}$ cell body. $A, C$, Nomarski contrast images of $\mathrm{SN}$ cell bodies and initial axon segments for different conditions are shown on the right, and corresponding immunocytochemical fluorescent images are presented on the left. These raw images were used to generate the pseudocolor representations in earlier figures. Scale bars, $25 \mu \mathrm{m}$. $A, B$, Granules containing syntaxin are detected in axon hillock and axon of SNs contacting $L 7$ on day 1 but are rare on day 5 . Granules $(A$, arrow) are detected in SNs contacting L7 on day 1. Few are detected in SNs contacting L7 on day 5 . Note the high intensity signal in the axon hillock of the $\mathrm{SN}$ on day 1 . The summary of the difference between day 1 and day 5 is shown in $B$. The number on day 1 is significantly greater than on day $5(F=8.410, p<0.01) . C, D$, Granules containing syntaxin are detected in axon hillock and axon of SNs after treatment with 5-HT that produces LTF. Granules (C, arrow) are detected in the SN axon after 5-HT. None are detected in the SN axon after control treatment. The fluorescent signal is high in the axon hillock of the SN treated with $5-H T$. The summary of the difference between controls and $5-\mathrm{HT}$ is shown in $D$. The number stained with 5 -HT is significantly greater than control $(F=14.010 ; p<$ 0.01).

washout of anisomycin (Fig. 8A,B). The PKA inhibitor KT5720, but not the PKC inhibitor chelerythrine, blocked the effect of 5-HT on the number of labeled granules in $\mathrm{SN}$ axons (Fig. $8 C, D$ ). We detected only $0.4 \pm 0.2$ granules when cultures were treated with KT5720 ( $n=7$ cultures) but detected $4.1 \pm 0.5$ granules when cultures were treated with chelerythrine ( $n=7$ cultures). When the redistribution of syntaxin mRNA is blocked (anisomycin and KT5720), there is a decrease in packaging of syntaxin for transport to distal sites that is normally produced by $5-\mathrm{HT}$.

\section{Discussion}

Our results indicate that the distribution of syntaxin mRNA in neuronal cell bodies can be regulated bi-directionally and can lead to corresponding changes in protein expression and packag- ing for transport in the axon. Syntaxin mRNA accumulates at the axon hillock of SNs during the initial phases of synapse formation. As synapses stabilize, syntaxin mRNA now accumulates in areas opposite from the axon hillock. Syntaxin mRNA is always distributed uniformly in the absence of any target or when SNs interact with a target that fails to initiate synapse formation. When cultures with stable synapses are exposed to repeated applications of 5-HT that produce LTF, the distribution of syntaxin mRNA reverts back to that expressed during the initial phases of synapse formation. This reversion in mRNA distribution with 5-HT requires new protein synthesis and activation of the PKA pathway. When syntaxin mRNA accumulates at the axon hillock, protein expression at the axon hillock increases, and the number of granules containing syntaxin detected in $\mathrm{SN}$ axons also increases. Thus altering the distribution of mRNA within the cell body without changing its overall expression can regulate the expression and packaging for export of a molecule critical for synaptic function.

The axon hillock of most neurons regulates electrical excitability and the maintenance of specialized features required for axon function. Some proteins and their mRNAs expressed selectively in axonal compartments are targeted to the axon hillock (Steward and Ribak, 1986; Litman et al., 1993; Behar et al., 1995; Hannan et al., 1998). The axon hillock also contains critical organelles and specific cytoskeleton organization required for axonal transport of both proteins and mRNA (Lindsey and Ellisman, 1985; Matsumura and Kohno, 1991; Braun et al., 1993; Olink-Coux and Hollenbeck, 1996; Bassell et al., 1998; Muslimov et al., 2002). Thus the targeting to the axon hillock of mRNAs encoding molecules critical for synaptic transmission such as syntaxin, as well as sensorin and apCAM (Hu et al., 2002), may facilitate their translation and subsequent transport to synapses.

The accumulation of syntaxin mRNA during the initial phases of synapse formation suggests that specific target interaction may upregulate expression of mRNA binding protein(s) or chaperones that target syntaxin mRNA to the axon hillock. Binding proteins such as staufen, FMRP (fragile X mental retardation protein), or the Hu/ELAV (embryonic lethal abnormal vision) family of binding proteins may facilitate the targeting of mRNA in mature neurons (Krichevsky and Kosik, 2001; Tang et al., 2001; O'Donnell and Warren, 2002; Perrone-Bizzozero and Bolognani; 2002). In the absence of a target or when SNs interact with L11, the failure to induce the expression of sufficient levels of binding protein or chaperone may explain the failure to accumulate syntaxin mRNA at any particular location. As the synapse 
becomes stable by day 5 in culture, syntaxin mRNA is expressed at similar levels as on day 1, but now appears to be excluded from the axon hillock. The exclusion from the axon hillock may result from the splicing of a site on syntaxin $\mathrm{mR}$ NAs that is recognized by binding proteins required for targeting (Aronov et al., 2001), a reduction or change in the relative levels of chaperone proteins that shuttle complexes containing both mRNA and protein to targeted sites (Monshausen et al., 2001), an increase in selective mRNA degradation at specific sites (Ding et al., 1993; Bashirullah et al., 2001), or selective stabilization at sites outside the axon hillock (Cooperstock and Lipshitz, 1997). These processes are selective, because sensorin mRNA continues to accumulate at the axon hillock as the synapse matures. In the absence of appropriate synaptic target, both syntaxin and sensorin mRNAs (Hu et al., 2002) are distributed uniformly within the SN cell body. Separate binding proteins, chaperones, or mechanisms regulated by synapse formation and stabilization as well as target interaction appear to regulate the bidirectional accumulation of different $\mathrm{mR}$ NAs at the axon hillock.

Target interaction with L7 leads to two events separated by time. The first event is to trigger accumulation of syntaxin mRNA at the axon hillock as synapses form. The second event signaled by the target is the exclusion of syntaxin mRNA from the axon hillock as synapses stabilize. This process unfolds continuously, because images of staining at intermediate times (e.g., day 3 ) reveal a more uniform distribution of syntaxin mRNA within the cytoplasm (data not shown). The exclusion of an mRNA encoding a molecule critical for synaptic transmission from the axon hillock and the consequences of this exclusion on protein expression and transport (see below) may play an important role in stabilizing synaptic strength or maintaining homeostasis for presynaptic output (K. Liu, J.-Y. Hu, D. Wang, S.

Schacher, unpublished observation). The identity of the retrograde signals from L7 mediating both targeting and exclusion is unknown. These changes in syntaxin mRNA distribution induced by specific target interaction join other retrograde actions of the target on SNs, including extent of neurite outgrowth and varicosity formation, expression and distribution of receptors to neuromodulators evoking synaptic plasticity, expression of structural plasticity accompanying long-term synaptic modulation, and transport of mRNA to distal sites and its stability at those sites (Glanzman et al., 1989, 1990; Schacher and Montarolo, 1991; Sun and Schacher, 1996; Schacher et al., 1999; Hu et al., 2002). The identity of these retrograde signals and how they produce the changes in SNs are under investigation.

The accumulation of syntaxin mRNA at the axon hillock dur- ing the initial phases of synapse formation and its exclusion when synapses stabilize are positively correlated with levels of protein expression at the axon hillock and the number of granules with syntaxin detected in the initial portions of the SN axon. This suggests that mRNA targeting in the $\mathrm{SN}$ cell body could regulate levels of syntaxin transported to distal SN release sites. High levels of syntaxin expression and transport during the initial phases of synapse formation may be critical for the development of release sites at varicosities (Noakes et al., 1999; Greenlee et al., 2001). Varicosity formation by SNs is highest during the first 2-3 d in culture (Bank and Schacher, 1992; Hatada et al., 1999). The reduction in syntaxin expression in the absence of an appropriate target correlates with the formation of far fewer SN varicosities and the absence of transmitter release sites (Glanz- 
man et al., 1989). As synapses stabilize there is a significant slowing of varicosity formation by SNs (Glanzman et al., 1990; Bank and Schacher, 1992). This is correlated with a reduction in syntaxin mRNA levels at the axon hillock and packaging of syntaxin for axonal transport. This apparent reduction in syntaxin expression in $\mathrm{SN}$ axons between day 1 and day 5 is not a result of an overall change in mRNA expression but correlates with a change in the distribution of syntaxin mRNA within the SN cell body. Thus post-transcriptional events regulated by interactions with a distant target neuron can affect the distribution of mRNA in the cell body of a presynaptic neuron that in turn may regulate the expression and transport of the translated protein to those distal sites. The presence of a significant pool of syntaxin mRNA "parked" in different areas of the cell body where its translation is likely to contribute to synaptic function only when the mRNA is in a particular location is a novel form of regulation in mature neurons.

The exclusion of syntaxin mRNA from the axon hillock of SNs with stable synapses is reversed in a protein synthesis-dependent manner by applications of 5-HT that produce LTF via activation of PKA. LTF produced by $5-\mathrm{HT}$ is accompanied by a number of cellular changes, including enhanced function from preexisting synaptic sites (Bailey and Chen, 1983; Santarelli et al., 1996; Sun and Schacher, 1998; Sherff and Carew, 1999; Hatada et al., 2000; Wainwright et al., 2002) and the formation of new SN varicosities (Bailey and Chen, 1988; Glanzman et al., 1990; Bailey et al., 1992; Martin et al., 1997; Casadio et al., 1999; Hatada et al., 2000; Wainwright et al., 2002). Many long-term cellular changes are produced by activation of the PKA pathway in SNs (Kandel and Schwartz, 1982; Greenberg et al., 1987; Schacher et al., 1988, 1993; Byrne et al., 1993; Muller and Carew, 1998; Casadio et al., 1999). Long-lasting change in synaptic efficacy appears to be correlated with long-lasting structural changes in the arbor of the SN (Bailey and Chen, 1988, 1989; Casadio et al., 1999; Wainwright et al., 2002). Changes in gene expression and protein synthesis are required for the expression of structural plasticity in SNs (Bailey et al., 1992; O’Leary et al., 1995; Casadio et al., 1999). Activation of the PKA pathway in SNs may now upregulate the same genes and proteins that serve to target syntaxin mRNA to the axon hillock during the initial phases of synapse formation. This may include the resumed synthesis of mRNA binding proteins or chaperones required for targeting (Aronov et al., 2002) or changes in mRNA splicing machinery by 5 -HT (Schacher et al., 2000) so that appropriate binding proteins can interact with syntaxin mRNA. Alternatively, the action of 5-HT may evoke a separate mechanism such as phosphorylation of mRNA binding proteins or other substrates involved with mRNA targeting (Angenstein et al., 2002). The change in mRNA distribution with 5-HT and PKA activation then leads to increased levels of syntaxin packaged for transport in the axon. In future experiments we will examine whether the same mechanisms regulate mRNA distribution when specific synapses form and when those same synapses mature and express synaptic plasticity.

\section{References}

Alberini CM, Ghirardi M, Metz R, Kandel ER (1994) C/EBP is an immediate-early gene required for the consolidation of long-term facilitation in Aplysia. Cell 76:1099-1114.

Angenstein F, Evans AM, Settlage RE, Moran ST, Ling S-C, Klintsova AY, Shabanowitz J, Hunt DF, Greenough WT (2002) A receptor for activated $\mathrm{C}$ kinase is part of messenger ribonucleoprotein complexes associated with poly A-mRNAs in neurons. J Neurosci 22:8827-8837.

Angers A, Fioravante D, Chin J, Cleary LJ, Bean AJ, Byrne JH (2002) Sero- tonin stimulates phosphorylation of Aplysia synapsin and alters its subcellular distribution in sensory neurons. J Neurosci 22:5412-5422.

Aronov S, Aranda G, Behar L, Ginzburg I (2001) Axonal tau mRNA localization coincides with tau protein in living neuronal cells and depends on axonal targeting signal. J Neurosci 21:6577-6587.

Aronov S, Aranda G, Behar L, Ginzburg I (2002) Visualization of translated tau protein in the axons of neuronal P19 cells and characterization of tau RNP granules. J Cell Sci 115:3817-3827.

Bacskai BJ, Hochner B, Mahaut-Smith M, Adams SR, Kaang BK, Kandel ER, Tsien RY (1993) Spatially resolved dynamics of cAMP and protein kinase A subunits in Aplysia sensory neurons. Science 260:222-226.

Bailey CH, Chen M (1983) Morphological basis of long-term habituation and sensitization in Aplysia. Science 220:91-93.

Bailey CH, Chen M (1988) Long-term memory in Aplysia modulates the total number of varicosities of single identified sensory neurons. Proc Natl Acad Sci USA 2373-2377.

Bailey CH, Chen M (1989) Time course of structural at identified sensory neuron synapse during long-term sensitization in Aplysia. J Neurosci 9:1774-1780

Bailey CH, Chen M, Montarolo PG, Kandel ER, Schacher S (1992) Inhibitors of protein and RNA synthesis block structural and functional changes accompanying long-term synaptic facilitation and inhibition in Aplysia sensory neurons. Neuron 9:749-758.

Bank M, Schacher S (1992) Segregation of presynaptic inputs on an identified target neuron in vitro: structural remodeling visualized over time. J Neurosci 12:2960-2972.

Bashirullah A, Cooperstock RL, Lipshitz HD (2001) Spatial and temporal control of RNA stability. Proc Natl Acad Sci USA 98:7025-7028.

Bassell GJ, Zhang H, Byrd AL, Femino AM, Singer RH, Taneja KL, Lifshitz LM, Herman IM, Kosik KS (1998) Sorting of $\beta$-actin mRNA and protein to neurites and growth cones in culture. J Neurosci 18:251-265.

Behar L, Marx R, Sadot E, Barg J, Ginzburg I (1995) Cis-acting signals and trans-acting proteins are involved in tau mRNA targeting into neurites of differentiating neuronal cells. Int J Dev Neurosci 13:113-127.

Bennett MK, Calakos N, Scheller RH (1992) Syntaxin: a synaptic protein implicated in docking of synaptic vesicles at presynaptic active zones. Science 257:255-259.

Blasi J, Binz T, Yamasaki S, Link E, Niemann H, Jahn R (1994) Inhibition of neurotransmitter release by clostridial neurotoxins correlates with specific proteolysis of synaptosomal proteins. J Physiol (Paris) 88:235-241.

Braun N, Schikorski T, Zimmermann H (1993) Cytoplasmic segregation and cytoskeletal organization in the electric catfish giant electromotoneuron with special reference to the axon hillock region. Neuroscience 52:745-756.

Byrne JH, Zwartjes R, Homayouni R, Critz SD, Eskin A (1993) Roles of second messenger pathways in neuronal plasticity and in learning and memory. Insights gained from Aplysia. Adv Second Messenger Phosphoprotein Res 27:47-108.

Casadio A, Martin KC, Giustetto M, Zhu H, Chen M, Bartsch D, Bailey CH, Kandel ER (1999) A transient, neuron-wide form of CREB-mediated long-term facilitation can be stabilized at specific synapses by local protein synthesis. Cell 99:221-237.

Chain DG, Casadio A, Schacher S, Hegde AN, Valbrun M, Yamamoto N, Goldberg AL, Bartsch D, Kandel ER, Schwartz JH (1999) Mechanisms for generating the autonomous cAMP-dependent protein kinase required for long-term facilitation in Aplysia. Neuron 22:147-156.

Cooperstock RL, Lipshitz HD (1997) Control of mRNA stability and translation during Drosophila development. Semin Cell Dev Biol 8:541-549.

Dash PK, Hochner B, Kandel ER (1990) Injection of the cAMP-responsive element into the nucleus of Aplysia sensory neurons blocks long-term facilitation. Nature 345:718-721.

Davis S, Rodger J, Hicks A, Mallet J, Laroche S (1996) Brain structure and task-specific increase in expression of the gene encoding syntaxin 1B during learning in the rat: a potential molecular marker for learning-induced synaptic plasticity in neural networks. Eur J Neurosci 8:2068-2074.

Davis S, Rodger J, Stephan A, Hicks A, Mallet J, Laroche S (1998) Increase in syntaxin 1B mRNA in hippocampal and cortical circuits during spatial learning reflects a mechanism of trans-synaptic plasticity involved in establishing a memory trace. Learn Mem 5:375-390.

Davis S, Salin H, Helme-Guizon A, Dumas S, Stephan A, Corbex M, Mallet J, Larache S (2000) Dysfunctional regulation of alphaCaMKII and syn- 
taxin $1 \mathrm{~B}$ transcription after induction of LTP in the aged rat. Eur J Neurosci 12:3276-3282.

Ding D, Parkhurst SM, Halsell SR, Lipshitz HD (1993) Dynamic hsp83 RNA localization during Drosophila oogenesis and embryogenesis. Mol Cell Biol 13:3773-3781.

Eliot LS, Hawkins RD, Kandel ER, Schacher S (1994) Pairing-specific, activity-dependent presynaptic facilitation at Aplysia sensory-motor neuron synapses in isolated cell culture. J Neurosci 14:368-383.

Glanzman DL, Kandel ER, Schacher S (1989) Identified target motor neuron regulates neurite outgrowth and synapse formation of Aplysia sensory neurons in vitro. Neuron 3:441-450.

Glanzman DL, Kandel ER, Schacher S (1990) Target-dependent structural changes accompanying long-term synaptic facilitation in Aplysia neurons. Science 249:799-802.

Greenberg SM, Castellucci VF, Bayley H, Schwartz JH (1987) A molecular mechanism for long-term sensitization in Aplysia. Nature 329:62-65.

Greenlee MH, Roosevelt CB, Sakaguchi DS (2001) Differential localization of SNARE complex proteins SNAP-25, syntaxin, and VAMP during development of the mammalian retina. J Comp Neurol 430:306-320.

Hannan AJ, Gunning P, Jeffrey PL, Weinberger RP (1998) Structural compartments within neurons: developmentally regulated organization of microfilament isoform mRNA and protein. Mol Cell Neurosci 11:289-304.

Hata Y, Slaughter CA, Sudhof TC (1993) Synaptic vesicle fusion complex contains unc-18 homologue bound to syntaxin. Nature 366:347-351.

Hatada Y, Wu F, Silverman R, Schacher S, Goldberg DJ (1999) En passant synaptic varicosities form directly from growth cones by transient cessation of growth cone advance but not of actin-based motility. J Neurobiol 41:242-251.

Hatada Y, Wu F, Sun ZY, Schacher S, Goldberg DJ (2000) Presynaptic morphological changes associated with long-term synaptic facilitation are triggered by actin polymerization at preexisting varicosities. J Neurosci 20:RC82(1-5).

Hegde AN, Inokuchi K, Pei W, Casadio A, Ghirardi M, Chain DG, Martin KC, Kandel ER, Schwartz JH (1997) Ubiquitin C-terminal hydrolase is an immediate-early gene essential for long-term facilitation in Aplysia. Cell 89:115-126.

Hicks A, Davis S, Rodger J, Helme-Guizon A, Laroche S, Mallet J (1997) Synapsin I and syntaxin 1B: key elements in the control of neurotransmitter release are regulated by neuronal activation and long-term potentiation in vivo. Neuroscience 79:329-340.

Hu JY, Meng X, Schacher S (2002) Target interaction regulates distribution and stability of specific mRNAs. J Neurosci 22:2669-2678.

Igarashi M, Kozaki S, Terakawa S, Kawano S, Ide C, Komiya Y (1996) Growth cone collapse and inhibition of neurite growth by Botulinum neurotoxin C1: a t-SNARE is involved in axonal growth. J Cell Biol 134:205-215.

Kandel ER, Schwartz JH (1982) Molecular biology of learning: modulation of transmitter release. Science 218:433-443.

Kislauskis EH, Zhu X, Singer RH (1994) Sequences responsible for intracellular localization of beta-actin messenger RNA also affect cell phenotype. J Cell Biol 127:441-451.

Krichevsky AM, Kosik KS (2001) Neuronal RNA granules: a link between RNA localization and stimulation-dependent translation. Neuron 32:683-696.

Lindsey JD, Ellisman MH (1985) The neuronal endomembrane system. III. The origins of the axoplasmic reticulum and discrete axonal cisternae at the axon hillock. J Neurosci 5:3135-3144.

Litman P, Barg J, Rindzoonski L, Ginzburg I (1993) Subcellular localization of tau mRNA in differentiating neuronal cell culture: implications for neuronal polarity. Neuron 10:627-638.

Martin KC, Casadio A, Zhu H, Rose JC, Chen M, Bailey CH, Kandel ER (1997) Synapse-specific, long-term facilitation of Aplysia sensory to motor synapses: a function for local protein synthesis in memory storage. Cell 91:927-938.

Matsumura A, Kohno K (1991) Microtubule bundles in fish cerebellar Purkinje cells. Anat Embryol (Berl) 183:105-110.

Monshausen M, Putz U, Rehbein M, Schweizer M, DesGroseillers L, Kuhl D, Richter D, Kindler S (2001) Two rat brain staufen isoforms differentially bind RNA. J Neurochem 76:155-165.

Montarolo PG, Goelet P, Castellucci VF, Morgan J, Kandel ER, Schacher S
(1986) A critical period for macromolecular synthesis in long-term heterosynaptic facilitation in Aplysia. Science 234:1249-1254.

Montarolo PG, Kandel ER, Schacher S (1988) Long-term heterosynaptic inhibition in Aplysia. Nature 333:171-174.

Muller U, Carew TJ (1998) Serotonin induces temporally and mechanistically distinct phases of persistent PKA activity in Aplysia sensory neurons. Neuron 21:1423-1434.

Muslimov IA, Titmus M, Koenig E, Tiedge H (2002) Transport of neuronal BC1 RNA in Mauthner axons. J Neurosci 22:4293-4301.

Noakes PG, Chin D, Kim SS, Liang S, Phillips WD (1999) Expression and localisation of dynamin and syntaxin during neural development and neuromuscular synapse formation. J Comp Neurol 410:531-540.

O'Donnell WT, Warren ST (2002) A decade of molecular studies of fragile X syndrome. Annu Rev Neurosci 25:315-338.

O’Leary FA, Byrne JH, Cleary LJ (1995) Long-term structural remodeling in Aplysia sensory neurons requires de novo protein synthesis during a critical time period. J Neurosci 15:3519-3525.

Olink-Coux M, Hollenbeck PJ (1996) Localization and active transport of mRNA in axons of sympathetic neurons in culture. J Neurosci 16:1346-1358.

Palacios IM, St. Johnston D (2001) Getting the message across: the intracellular localization of mRNAs in higher eukaryotes. Annu Rev Cell Dev Biol 17:569-614.

Perrone-Bizzozero N, Bolognani F (2002) Role of HuD and other RNAbinding proteins in neural development and plasticity. J Neurosci Res 68:121-126.

Rayport SG, Schacher S (1986) Synaptic plasticity in vitro: cell culture of identified Aplysia neurons mediating short-term habituation and sensitization. J Neurosci 6:759-763.

Sanders JD, Yang Y, Liu Y (1998) Differential turnover of syntaxin and SNAP-25 during synaptogenesis in cultured cerebellar granule neurons. J Neurosci Res 53:670-676.

Santarelli L, Montarolo P, Schacher S (1996) Neuropeptide localization in varicosities of Aplysia sensory neurons is regulated by target and neuromodulators evoking long-term synaptic plasticity. J Neurobiol 31:297-308.

Schacher S, Montarolo PG (1991) Target-dependent structural changes in sensory neurons of Aplysia accompany long-term heterosynaptic inhibition. Neuron 6:679-690.

Schacher S, Wu F (2002) Synapse formation in the absence of cell bodies requires protein synthesis. J Neurosci 22:1831-1839.

Schacher S, Castellucci VF, Kandel ER (1988) cAMP evokes long-term facilitation in Aplysia sensory neurons that requires new protein synthesis. Science 240:1667-1669.

Schacher S, Kandel ER, Montarolo P (1993) cAMP and arachidonic acid simulate long-term structural and functional changes produced by neurotransmitters in Aplysia sensory neurons. Neuron 10:1079-1088.

Schacher S, Wu F, Panyko JD, Sun ZY, Wang D (1999) Expression and branch-specific export of mRNA are regulated by synapse formation and interaction with specific postsynaptic targets. J Neurosci 19: $6338-6347$.

Schacher S, Wu F, Sun ZY, Wang D (2000) Cell-specific changes in expression of mRNAs encoding splice variants of Aplysia cell adhesion molecule accompany long-term synaptic plasticity. J Neurobiol 45:152-161.

Sherff CM, Carew TJ (1999) Coincident induction of long-term facilitation in Aplysia: cooperativity between cell bodies and remote synapses. Science 285:1911-1914.

Skehel PA, Armitage BA, Bartsch D, Hu Y, Kaang BK, Siegelbaum SA, Kandel ER, Martin KC (1995) Proteins functioning in synaptic transmission at the sensory to motor synapse of Aplysia. Neuropharmacology 34:1379-1385.

Smirnova T, Fossier P, Stinnakre J, Mallet J, Baux G (1995) A syntaxinrelated protein controls acetylcholine release by different mechanisms in Aplysia. Neuroscience 68:125-133.

Sossin WS, Sacktor TC, Schwartz JH (1994) Persistent activation of protein kinase C during the development of long-term facilitation in Aplysia. Learn Mem 1:189-202.

Steward O, Ribak CE (1986) Polyribosomes associated with synaptic specializations on axon initial segments: localization of protein-synthetic machinery at inhibitory synapses. J Neurosci 6:3079-3085.

Steward O, Schuman EM (2001) Protein synthesis at synaptic sites on dendrites. Annu Rev Neurosci 24:299-325. 
Steward O, Worley PF (2001) A cellular mechanism for targeting newly synthesized mRNAs to synaptic sites on dendrites. Proc Natl Acad Sci USA 98:7062-7068.

Sun ZY, Schacher S (1996) Development of short-term heterosynaptic facilitation at Aplysia sensorimotor synapses in vitro is accompanied by changes in the functional expression of presynaptic serotonin receptors. J Neurophysiol 76:2250-2261.

Sun ZY, Schacher S (1998) Binding of serotonin to receptors at multiple sites is required for structural plasticity accompanying long-term facilitation of Aplysia sensorimotor synapses. J Neurosci 18:3991-4000.

Sun ZY, Kauderer B, Schacher S (1996) Differential distribution of functional receptors for neuromodulators evoking short-term heterosynaptic plasticity in Aplysia sensory neurons. J Neurosci 16:7540-7549.
Sutton MA, Carew TJ (2000) Parallel molecular pathways mediate expression of distinct forms of intermediate-term facilitation at tail sensorymotor synapses in Aplysia. Neuron 26:219-231.

Tang SJ, Meulemans D, Vazquez L, Colaco N, Schuman E (2001) A role for a rat homolog of staufen in the transport of RNA to neuronal dendrites. Neuron 32:463-475.

Wainwright ML, Zhang H, Byrne JH, Cleary LJ (2002) Localized neuronal outgrowth induced by long-term sensitization training in Aplysia. J Neurosci 22:4132-4141.

Wu F, Friedman L, Schacher S (1995) Transient versus persistent functional and structural changes associated with facilitation of Aplysia sensorimotor synapses are second messenger dependent. J Neurosci 15:7517-7527. 